\title{
2 Glass powder as replacement of cement for concrete - An investigative
}

3

4

5

6 Mr Zameer Kalakada, Higher Degree Research Candidate, Structural Engineering, School of

7 Engineering and Built Environment, Griffith University, Gold Coast Campus, QLD 4222,

8 Building (G06) Room 1.33, Tel - +61 488728028, Email -

9 zameer.kalakada@griffithuni.edu.au

10 study

Zameer Kalakada, Jeung Hwan-Doh* \& Sanaul Chowdhury

School of Engineering and Built Environment, Griffith University, Gold Coast, Australia.

Dr Jeung Hwan-Doh, Senior Lecturer, Structural Engineering, School of Engineering and Built Environment, Griffith University, Gold Coast Campus, QLD 4222, Building (G09) Room 1.24, Tel - +61 75552 9141, Fax - +61 75552 8065, Email - j.doh@griffith.edu.au

Dr Sanaul Chowdhury, Senior Lecturer, Structural Engineering, School of Engineering and Built Environment, Griffith University, Gold Coast Campus, QLD 4222, Building (G09) Room 1.16, Tel - +61 75552 8662, Fax - +61 75552 8065, Email s.h.chowdhury@griffith.edu.au 


\title{
Glass powder as replacement of cement for concrete - An investigative study
}

\begin{abstract}
Cement production involves extensive energy absorption and emits huge quantities of $\mathrm{CO}_{2}$ in the atmosphere. The production rates are increasing annually to meet the ever increasing demand with increased energy absorption and $\mathrm{CO}_{2}$ emission. Hence, it is imperative to use materials which can replace use of cement to some extent. Conversely, waste glass is being dumped in the landfills. This practice is environmentally unsustainable since glass is nonbiodegradable. Recently it's revealed that glass when grinded to a particular fineness exhibits cementitious properties due to pozzolanic reaction. This paper investigates the fresh, mechanical and durability properties of concretes made with cement replaced by coarse glass powder $(<150 \mu \mathrm{m})$ at various replacement levels and employing different curing conditions. The replacement levels employed were $0 \%, 15 \%, 30 \%$ and $50 \%$ by weight of cement, while the curing regimes followed were ambient, Elevated Temperature Curing (ETC) @ $40^{\circ} \mathrm{C}$ and water. Scanning electron microscopy (SEM) and X-ray fluorescence (XRF) techniques were performed on cement and glass powder to investigate the microstructure and chemical composition of the materials. The initial findings show that $30 \%$ is the ideal replacement level as it exhibits quite comparable strengths, better workability and higher resistance to chloride ion penetration compared to the control mix.
\end{abstract}

Keywords: Waste glass powder, Cement, Pozzolanic activity, Compressive strength, Chloride penetration.

\section{Introduction}

Cement, the main ingredient in concrete which gives strength and serves the purpose of binding the other ingredients together is produced in enormous quantities. It is estimated that around 85.9 million metric tons of cement is produced in the United States alone, while the worldwide production is amounting to a staggering 4,200 million metric tons [1]. Manufacturing of cement is a highly polluting and energy-intensive process, which caters to around $12-15 \%$ of industrial energy consumption besides $5-7 \%$ of all carbon dioxide $\left(\mathrm{CO}_{2}\right)$ discharge [2]. To make matters worse, Szabó et. al [3] predicted that by the year 2030, there would be a $50 \%$ increase in the global $\mathrm{CO}_{2}$ emissions from cement industry owing to rise in cement production to meet the ever increasing demand. This sharp rise in $\mathrm{CO}_{2}$ outflow is believed to be responsible for the earth's climatic changes and the global warming [4]. Gopalakrishnan and Govindarajan [5] suggested replacing cement with either a solid waste material or an industrial by-product as a feasible option for reducing the cement consumption which eventually would result in environmental preservation. Employing industrial byproducts like fly ash, silica fume, and blast furnace slag in place of cement depicted a valueadded procedure to address the environmental issues. Hence, for sustainability and green construction, recycled waste materials are preferred in construction industry [6-11].

In recent years, focus has shifted to using waste glass in the construction industry [12-14]. Glass is being recycled in many countries since its physical and chemical properties do not alter even after multiple usage [15]. However, recycling of huge quantities of glass is not 
possible owing to breaking, colour mixing and expensive recycling cost. The glass which is not recycled ends up in landfills and since glass is non-biodegradable, this practice is again environmentally unsustainable. In a recent report, it was stated that Australia generates around 1.1 million tons of glass waste annually with approximately $44 \%$ of it being dumped in the landfills [16]. The situation is more precarious in some other countries. Hence, waste glass has become a challenge for the waste management globally due to low recycling rate, limited landfill spaces and shortage in new spaces for landfills [17-18].

At first, waste glass was used as a fine aggregate replacement in concrete and it was observed that the mechanical and durability properties of the modified concrete were degraded due to the increased potential of Alkali-Silica Reaction (ASR) [19-21]. The main reason for this deterioration was due to high percentage of silica in glass culets which increased the chances of ASR in the concrete. According to the literature, ASR is a deleterious expansion occurring in concrete due to the reaction between siliceous minerals present in aggregate and the alkaline pore solution in concrete [22]. Later, investigations have shown that ASR occurrence in concrete is dependent on the particle size distribution of glass used - as the particle size decreases, the ASR probability reduces $[15,23]$. The suppressive effect of glass powders on the ASR expansion in concrete was due to the pozzolanic characteristic of glass powder, similar to other pozzolanic materials such as fly ash, silica fume and metakaolin [24, 25]. These results, motivated the use of recycled glass powder with microscopic particle size distribution as cement replacement.

Experimental investigations have shown that glass when grinded to about $300 \mu \mathrm{m}$ showed negligible ASR and these findings are in agreement with the maximum particle size of $300 \mu \mathrm{m}$ for ASR occurrence [15, 26-28]. Mehta [29] stated that the glass particles start to behave as a pozzolanic material at approximately below $300 \mu \mathrm{m}$ and when the fineness is reduced to about $100 \mu \mathrm{m}$ the pozzolanicity of the glass exceeds that of fly ash at low cement replacement levels and after curing for 90 days. The pozzolanic property of glass increases with the fineness of the glass and, as the particle size distribution reduces, the pozzolanic ability of the glass increases. Studies as early as 2000 , have been reported in the literature pertaining to the Glass Powder (GP) as cement replacement. In these studies, the size of the glass particle used ranged from $0-150 \mu \mathrm{m}$ [23]. Of late, the researchers concentrated on finer glass particle size ranging from $0-100 \mu \mathrm{m}$ and the maximum percentage of cement replacement is $60 \%$ [30-33].Some of the studies pertaining to GP as binder replacement are listed in Table 1. There is no consensus about the ideal cement replacement percentage, as the performance of the glass powder concrete is dependent on various factors including the type of glass, particle size distribution and chemical composition of the glass.

Majority of the work done in the past, employed a finer GP $(<100 \mu \mathrm{m})$ as binder replacement. The present study investigates the pozzolanic characteristics of a coarser GP $(<150 \mu \mathrm{m})$ subjected to three different curing regimes. In addition to the standard compressive strength measurements, fresh and durable attributes of the GP mortars were assessed by measuring the slump and resistance to chloride ion penetration. Finally, the performance of the GP mixes exposed to distinct curing conditions are compared with a reference mix with $0 \%$ GP to obtain the optimum replacement level of the GP under investigation. 
Table 1 GP as binder in concrete - A Literary Summary (Note: $\mathrm{d}_{50}$ is average particle size).

\begin{tabular}{|c|c|c|c|c|c|}
\hline $\begin{array}{l}\text { Size of the GP } \\
(\mu \mathrm{m})\end{array}$ & $\begin{array}{c}\text { Max } \\
\operatorname{rep}(\%)\end{array}$ & $\begin{array}{l}\text { Glass } \\
\text { type }\end{array}$ & Experimental parameters & Properties tested & Reference \\
\hline $\mathrm{GP}<100$ & 30 & $\begin{array}{l}\text { Soda } \\
\text { lime }\end{array}$ & \% rep $(10,20,30) @$ w/b = 0.38 & $\begin{array}{l}\text { Creep, Elastic modulus \& } \\
\text { Compressive strength }\end{array}$ & 34 \\
\hline $\mathrm{GP}<100$ & 30 & $\begin{array}{l}\text { Bottle } \\
\text { glass }\end{array}$ & \% rep $(10,20,30) @$ w/b $=0.72$ & $\begin{array}{l}\text { Mixing method on fresh \& } \\
\text { hardened properties }\end{array}$ & 35 \\
\hline $\begin{array}{l}\mathrm{GP} 1<75 \\
\mathrm{GP} 2<63\end{array}$ & 20 & - & \% rep $(5,10,15,20) @$ w/b = 0.4 & $\begin{array}{l}\text { Fresh, Mechanical \& } \\
\text { Durability }\end{array}$ & 36 \\
\hline $\mathrm{GP}<75$ & 20 & $\begin{array}{l}\text { Plate } \\
\text { glass }\end{array}$ & 20\% rep@ @ w/b=0.35 & Mechanical \& Durability & 37 \\
\hline $\begin{array}{l}0-100(40 \% \\
\mathrm{GP} \leq 10)\end{array}$ & 60 & $\begin{array}{l}\text { Soda } \\
\text { lime }\end{array}$ & \% rep $(15,30,45,60) @$ w/b = 0.49 & Mechanical \& Durability & 33 \\
\hline $\begin{array}{l}\text { Fine GP }(<50) \\
\text { Coarse GP(125 } \\
\quad-200)\end{array}$ & 30 & $\begin{array}{l}\text { Soda } \\
\text { lime }\end{array}$ & $\begin{array}{c}\text { Fine and coarse GPs @ 30\% rep, w/b = } 0.4 \text { (SEM-EDX } \\
\text { XRD, ASR), w/b = } 0.5 \text { (pore solution squeezes) }\end{array}$ & $\begin{array}{l}\text { Solid phases, Pore } \\
\text { solution \& ASR }\end{array}$ & 38 \\
\hline $\begin{array}{l}\text { GP1 \& GP2- } \\
\quad\left(\mathrm{d}_{50}=8.4\right)\end{array}$ & 20 & $\begin{array}{l}\text { Milled } \\
\text { glass } \\
\text { fibres }\end{array}$ & \% rep $(5,10,15,20) @$ w/b = 0.5 & $\begin{array}{l}\text { Hydration \& } \\
\text { Microstructure }\end{array}$ & 31 \\
\hline $\mathrm{GP}<75$ & 25 & - & $\begin{array}{l}\text { \% rep }(5,10,15,20,25) @ \mathrm{w} / \mathrm{b}=0.5 \text { in control mix } 1 \\
\% \text { rep }(5,10,15,20,25) @ \mathrm{w} / \mathrm{b}=0.35 \text { in control mix } 2\end{array}$ & Physical \& Mechanical & 39 \\
\hline $\mathrm{GP}<40\left(\mathrm{~d}_{50}=12\right)$ & 30 & - & $\begin{array}{l}\text { Interior slabs (10\% rep), Exterior slabs/sidewalks ( } 20 \% \\
\text { rep), Exterior structural wall elements (10\% \& } 30 \% \text { rep) }\end{array}$ & $\begin{array}{l}\text { Fresh, Mechanical \& } \\
\text { Durability }\end{array}$ & 32 \\
\hline $\begin{array}{l}0-100(40 \% \\
\mathrm{GP} \leq 10)\end{array}$ & 45 & $\begin{array}{l}\text { Bottle } \\
\text { glass }\end{array}$ & \% rep $(15,30,45) @$ w/b = 0.45 in control mix & Sulfuric acid attack & 40 \\
\hline $\begin{array}{l}\text { GP1 \& GP2- } \\
\quad\left(\mathrm{d}_{50}=8.4\right)\end{array}$ & 20 & $\begin{array}{l}\text { Industrial } \\
\text { by } \\
\text { product }\end{array}$ & \% rep $(5,10,15,20) @$ w/b = 0.5 & Mechanical \& Durability & 41 \\
\hline $\begin{array}{c}0-100 \\
(40 \% \mathrm{GP} \leq 10)\end{array}$ & 30 & $\begin{array}{l}\text { Milled } \\
\text { glass }\end{array}$ & \% rep $(5,10,15,20,25,30) @ \mathrm{w} / \mathrm{b}=0.51$ in control mix & Workability & 42 \\
\hline
\end{tabular}




\begin{tabular}{|c|c|c|c|c|c|}
\hline$\left(d_{50}=3.4\right)$ & 60 & $\begin{array}{l}\text { Soda } \\
\text { lime }\end{array}$ & \% rep $(15,30,45,60) @ \mathrm{w} / \mathrm{b}=0.49$ in control mix & Durability & 30 \\
\hline $\begin{array}{l}\text { Clear \& Green } \\
\text { glass }(0-25)\end{array}$ & 25 & $\begin{array}{l}\text { Window } \\
\text { \& bottle } \\
\text { glass }\end{array}$ & $\begin{array}{l}\text { Pozzolanicity of clear \& green glass at three diff curing } \\
\text { temp }\left(10,23 \& 50^{\circ} \mathrm{C}\right)\end{array}$ & $\begin{array}{l}\text { Hydration rate, } \\
\text { Mechanical \& Durability }\end{array}$ & 43 \\
\hline$\left(d_{50}=10\right)$ & 60 & $\begin{array}{l}\text { Beer } \\
\text { bottles }\end{array}$ & \% rep $(15,30,45,60) @ \mathrm{w} / \mathrm{b}=0.49$ in control mix & Particle size on ASR & 28 \\
\hline$\left(d_{50}=10\right)$ & 20 & $\begin{array}{l}\text { Car wind } \\
\text { screens }\end{array}$ & \% rep $(10,20) @ \mathrm{w} / \mathrm{b}=0.5$ in control mix & $\begin{array}{l}\text { Fresh, Mechanical \& } \\
\text { Durability }\end{array}$ & 44 \\
\hline$\left(d_{50}=20\right)$ & 20 & $\begin{array}{c}\text { Industrial } \\
\text { by } \\
\text { product }\end{array}$ & \% rep $(10,20) @$ w/b = 0.4 & $\begin{array}{l}\text { Chloride transport test on } \\
\text { microstructure }\end{array}$ & 13 \\
\hline$\left(d_{50}=45\right)$ & 20 & - & $\begin{array}{c}\text { 20\% rep of cement, Influence of GP on expansion } \\
\text { induced by ASR }\end{array}$ & ASR & 22 \\
\hline $10-15$ & 30 & $\begin{array}{l}\text { Soda } \\
\text { lime }\end{array}$ & \% rep $(20,30) @ \mathrm{w} / \mathrm{b}=0.49$ in control mix & $\begin{array}{l}\text { Mechanical \& Durability } \\
\text { (Field conditions) }\end{array}$ & 45 \\
\hline $\begin{array}{c}\text { GP fine }(40- \\
700), \\
\text { GP } \\
\operatorname{dust}(20 \% \leq 10) \\
\text { GP } 4000(0- \\
300), \\
\text { GP 6000(0- } \\
100)\end{array}$ & 20 & $\begin{array}{l}\text { Glass } \\
\text { beads }\end{array}$ & $\begin{aligned} \text { GP fine (20\% rep) }, \mathrm{w} / \mathrm{b} & =0.465, \mathrm{GP} \text { dust (20\% rep) }, \mathrm{w} / \mathrm{b} \\
& =0.471 \\
\text { GP } 4000 \text { (20\% rep) }, \mathrm{w} / \mathrm{b} & =0.480, \text { GP } 6000 \text { (20\% rep) } \\
\mathrm{w} / \mathrm{b} & =0.485\end{aligned}$ & Mechanical \& ASR & 46 \\
\hline $\begin{array}{c}75<\mathrm{GP} 1<150 \\
38<\mathrm{GP} 2<75 \\
\mathrm{GP} 3<38\end{array}$ & 30 & $\begin{array}{l}\text { Soda } \\
\text { lime }\end{array}$ & $30 \%$ rep by volume of GP1, GP2 \& GP3 & $\begin{array}{l}\text { Lime glass, Compressive } \\
\text { strength \& ASR }\end{array}$ & 23 \\
\hline
\end{tabular}




\section{Experimental program}

\subsection{Materials}

The cement used in the current study was CEMIX general purpose cement, which complies with all the regulations and requirements highlighted in AS 3972 [47] for general purpose and blended cement. The GP utilised in this investigative study was provided by Envirosand, a company located in Brisbane, Australia. Envirosand creates GP by first collecting waste and sorting it using a shaker machine. The glass is then crushed into the appropriate sizes and stored in a controlled environment. GP furnished for the current study was of two different sizes, one with finer particle size distribution of $75 \mu \mathrm{m}$ and the other with a coarser size of $150 \mu \mathrm{m}$. The fine aggregate used was EASY MIX double-washed river sand, which was provided by Griffith University. A sieve analysis was performed the results of which can be seen in Figure 1. The specific gravity, fineness modulus and water absorption of fine aggregate was 2.48, 2.5 and $1.5 \%$ respectively. The water used in this study was normal tap water from Griffith University. It was taken at room temperature of approximately $20^{\circ} \mathrm{C}$.

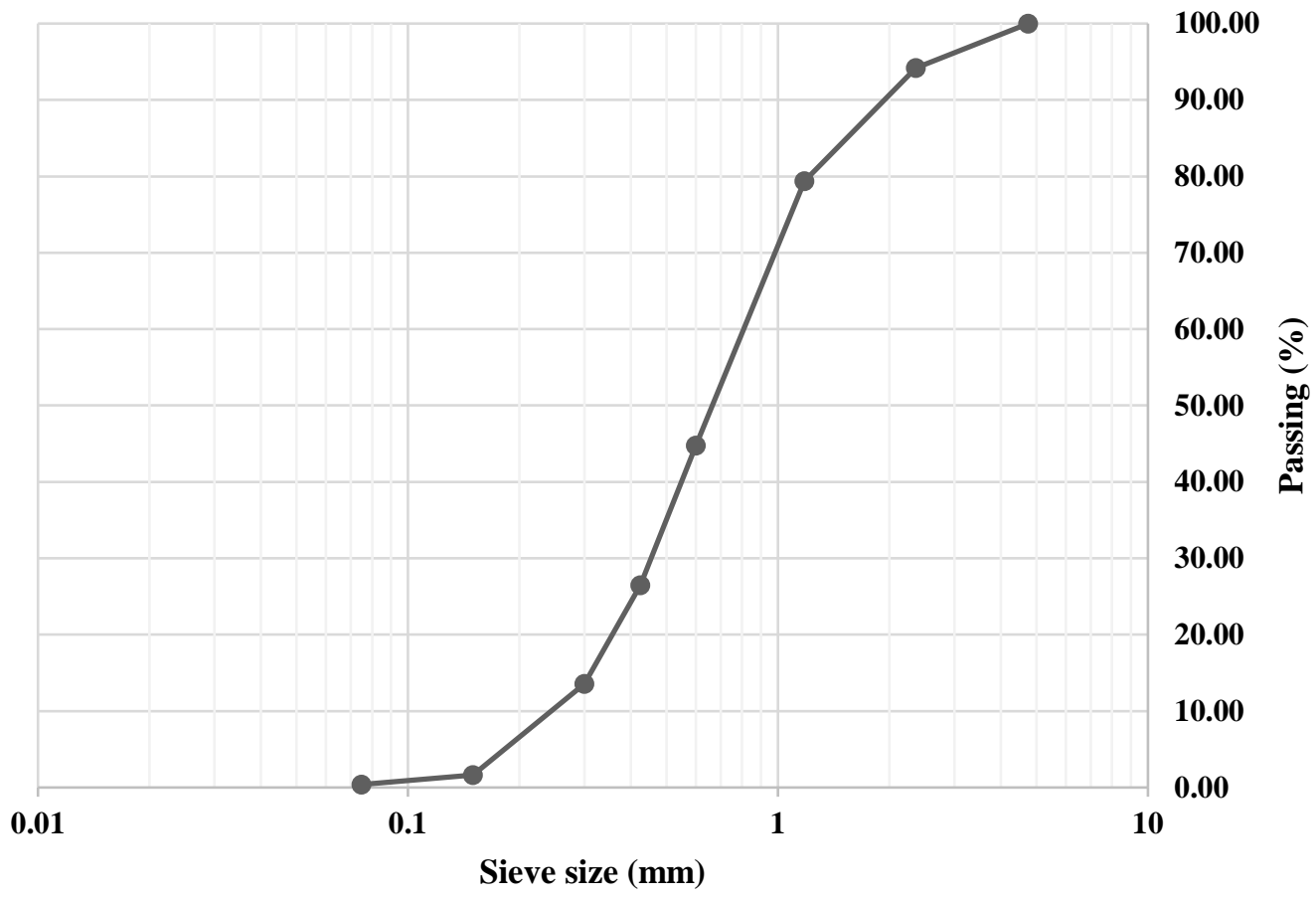

Figure 1. Particle size distribution of fine aggregate.

Elemental composition of cement and GP is determined using X-ray fluorescence (XRF) technique, the results of which are given in Table 2 . Since the sum of three oxides $\left(\mathrm{SiO}_{2}, \mathrm{Al}_{2} \mathrm{O}_{3}\right.$ and $\left.\mathrm{Fe}_{2} \mathrm{O}_{3}\right)$ of GP is greater than $70 \%$, it qualifies for the requirements of a cementitious material to be used as pozzolan (Class N/F/C) according to ASTM C618 [48]. Scanning Electron Microscopy (SEM) was carried on cement and GPs with different levels of magnifications, the results of which are illustrated in Figure 1.

Table 2 Chemical composition of cement and GP.

\begin{tabular}{ccc}
\hline Composition & Cement & Glass Powder \\
\hline $\mathrm{SiO}_{2}$ & 21.00 & 69.77
\end{tabular}




\begin{tabular}{ccc}
$\mathrm{Al}_{2} \mathrm{O}_{3}$ & 5.50 & 1.42 \\
$\mathrm{Fe}_{2} \mathrm{O}_{3}$ & 3.25 & 0.29 \\
$\mathrm{CaO}$ & 63.50 & 10.00 \\
$\mathrm{MgO}$ & 2.05 & 0.67 \\
$\mathrm{SO}_{3}$ & 2.15 & 0.19 \\
Alkalies $\left(\mathrm{Na}_{2} \mathrm{O}, \mathrm{K}_{2} \mathrm{O}\right)$ & 0.85 & 12.53 \\
\hline
\end{tabular}

151

152
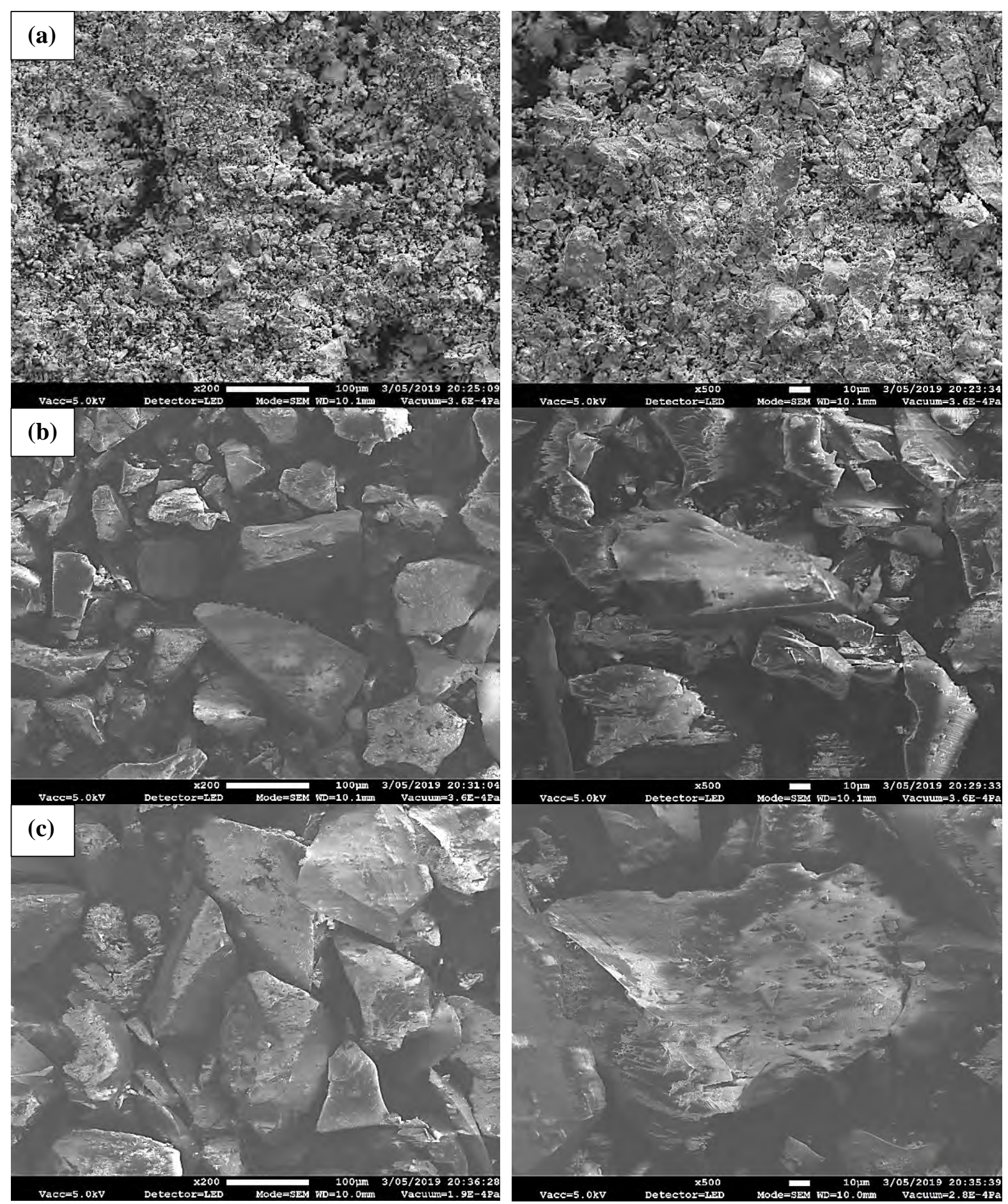

Figure 2. SEM images at x200 and x500: (a) Cement; (b) Fine GP $<75 \mu \mathrm{m}$; and (c) Coarse $\mathrm{GP}<150 \mu \mathrm{m}$. 


\subsection{Experimental parameters}

The investigative experimental study was performed in two stages: first stage comprised of employing same mix design for the concrete with GPs of two different sizes and the second stage involved subjecting concrete specimens prepared with coarse GP to different curing regimes. A weight based mix design for the concrete was employed in both the stages and the replacement levels employed were $0 \%, 15 \%, 30 \%$ and $50 \%$ as shown in Table 3 . For Stage 1, over 100 cylinders were cast for both the GPs. Each mix had 15 cylinders out of which 5 cylinders were tested at each curing age. While for Stage 2 about 180 cylinders were prepared, each mix had 45 cylinders, 15 specimens from each mix were subjected to three different curing conditions. Similar to Stage 1, the average of 5 samples was taken as the final value at every testing age for calculating the density, strength and chloride resistance. Overall, about 300 cylinders were cast in both stages for the investigative study.

Table 3 Mix proportions of mixes.

\begin{tabular}{|c|c|c|c|c|c|c|c|}
\hline & Mix & $\begin{array}{l}\text { GP } \\
(\%)\end{array}$ & $\begin{array}{c}\text { Water } \\
\left(\mathrm{kg} / \mathrm{m}^{3}\right)\end{array}$ & $\begin{array}{l}\text { Cement } \\
\left(\mathrm{kg} / \mathrm{m}^{3}\right)\end{array}$ & $\begin{array}{c}\mathrm{GP} \\
\left(\mathrm{kg} / \mathrm{m}^{3}\right)\end{array}$ & $\mathrm{S}\left(\mathrm{kg} / \mathrm{m}^{3}\right)$ & $\mathrm{W} /(\mathbf{C}+\mathbf{G P})$ \\
\hline \multirow{4}{*}{ 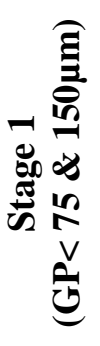 } & M1 & 0 & 240 & 600 & 0 & 630 & 0.40 \\
\hline & M2 & 15 & 240 & 510 & 90 & 630 & 0.40 \\
\hline & M3 & 30 & 240 & 420 & 180 & 630 & 0.40 \\
\hline & M4 & 50 & 240 & 300 & 300 & 630 & 0.40 \\
\hline \multirow{4}{*}{ 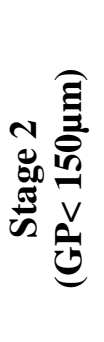 } & M1 & 0 & 210 & 600 & 0 & 630 & 0.35 \\
\hline & M2 & 15 & 210 & 510 & 90 & 630 & 0.35 \\
\hline & M3 & 30 & 210 & 420 & 180 & 630 & 0.35 \\
\hline & M4 & 50 & 210 & 300 & 300 & 630 & 0.35 \\
\hline
\end{tabular}

Three different curing conditions were employed to evaluate the pozzolanic behaviour of GP as shown in the Figure 3. For ambient curing, after 24 hours the cylinders were removed from the mould and kept in a room at a controlled temperature and humidity until the testing age. Elevated Temperature Curing (ETC) was done at $40^{\circ} \mathrm{C}$, cylinders were kept in a chamber for 24 hours at a constant temperature of $40^{\circ} \mathrm{C}$, and subsequently the samples were removed from the chamber and kept in the room under ambient conditions until the testing time. Water curing was done by immersing and keeping the cylinders submerged in limewater bath until testing time, this process of curing is complaint with the Australian standard AS 1012.8.1 [49]. 


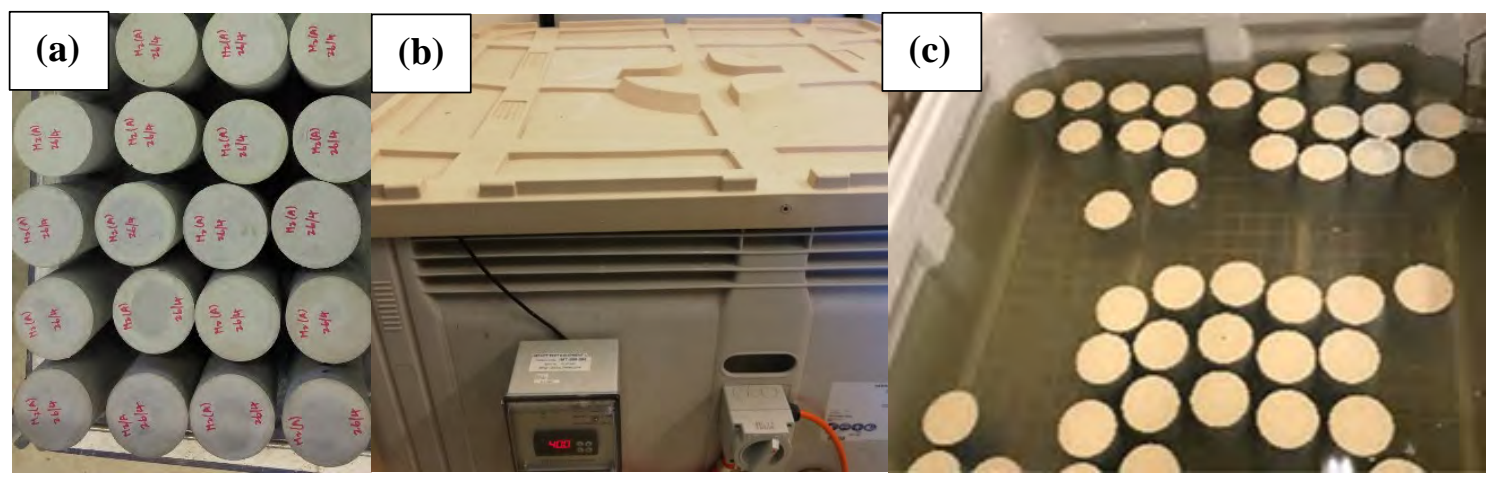

Figure 3. Curing regimes employed: (a) ambient; (b) ETC@40 $\mathrm{C}$; and (c) water.

\subsection{Tests}

Fresh and mechanical properties like workability and compressive strength were evaluated in the first stage while stage two had hardened density and resistance to chloride ion penetration evaluation besides the tests mentioned in stage one. The workability of the fresh concrete is determined by slump cone test in accordance with the standard AS 1012.3.1 [50]. AS 1012.12 [51] was used to measure the hardened density of cylindrical samples at 7, 28 and 91 days of curing. The compressive strength tests for all the concrete cylinders was performed at 7, 28 and 91 days of curing in accordance with AS 1012.9 [52]. An average of five cylinders was taken for each testing age in order to keep the standard deviation to a bare minimum.

Resistance to chloride ion penetration was evaluated by using Resipod which complies with the standard AASHTO TP 95 [53]. Resipod is a fully integrated 4-point Wenner probe used to measure the electrical resistivity of concrete cylinders non-destructively. Current is applied at the two outer probes and the resulting potential difference between the two inner probes is reported as the resistivity of the specimen, the ions in the pore liquid carry the applied current. This test method covers the laboratory evaluation of the electrical resistivity of concrete samples to provide a rapid indication of their resistance to chloride ion penetration. For each cylinder, an average of eight readings is taken and the final resistivity value is expressed in $\mathrm{k} \Omega \mathrm{cm}$. Based on the resistance value, the chloride ion permeability can be predicted from Table 4. As expected, higher the resistance lower would be the chloride permeability and vice versa. In majority of the cases, the resistivity results from the Resipod have shown a good correlation with chloride exposure tests, like ASTM C-1556, on cylinders cast from the same concrete mix [54]. In comparison with rapid chloride permeability test, the resistivity test is much quicker and easier for measuring the chloride permeability.

Table 4 Probability of chloride ion penetration based on measured resistivity [53].

\begin{tabular}{|c|c|}
\hline Chloride Ion Penetrability & 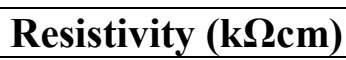 \\
\hline High & $<12$ \\
\hline Moderate & $12-21$ \\
\hline Low & $21-37$ \\
\hline Very Low & $37-254$ \\
\hline Negligible & $>254$ \\
\hline
\end{tabular}




\subsection{Specimens}

Concrete cylinders of dimension $100 \mathrm{~mm}$ (diameter) and $200 \mathrm{~mm}$ (height) were prepared in accordance with AS 1012.8.1 [49]. Cylindrical moulds were filled in two approximate equal layers and compaction was done by rodding 25 strokes per layer. Concrete cylinders were cured in a moist room at more than 95\% relative humidity and at a temperature of $23 \pm 2{ }^{\circ} \mathrm{C}$ for $24 \mathrm{~h}$, and then demolded, identified and subjected to the respective curing conditions until the testing age.

\section{Results and discussions}

Since the experimental work done in Stage 1 was to finalise the size of the GP to be used in Stage 2, and also for brevity, the results of Stage 1 are not discussed elaborately herein in this paper. Stage 2 results are presented in the following sections in some detail.

\subsection{Stage 1 results}

\subsubsection{Workability - Stage 1}

The workability of the mixes is given in Figure 4. It is clearly evident that as the GP content increases the slump value rises until 30\% replacement and then the trend reverses in both the GPs employed. Out of the two GPs used, the coarse GP performed better than its finer counterpart at all replacement levels. The workability results of coarse GP were almost double that of the fine GP especially at substitution levels of 15\% and 30\%. GP replacement of 30\% gave the maximum slump of $70 \mathrm{~mm}$ and $130 \mathrm{~mm}$ with fine and coarse GP respectively while the control mix at $0 \%$ GP could manage a modest workability of $50 \mathrm{~mm}$. Based on the slump results, $30 \%$ is the ideal replacement level as it gave the maximum workability with both the GPs employed.

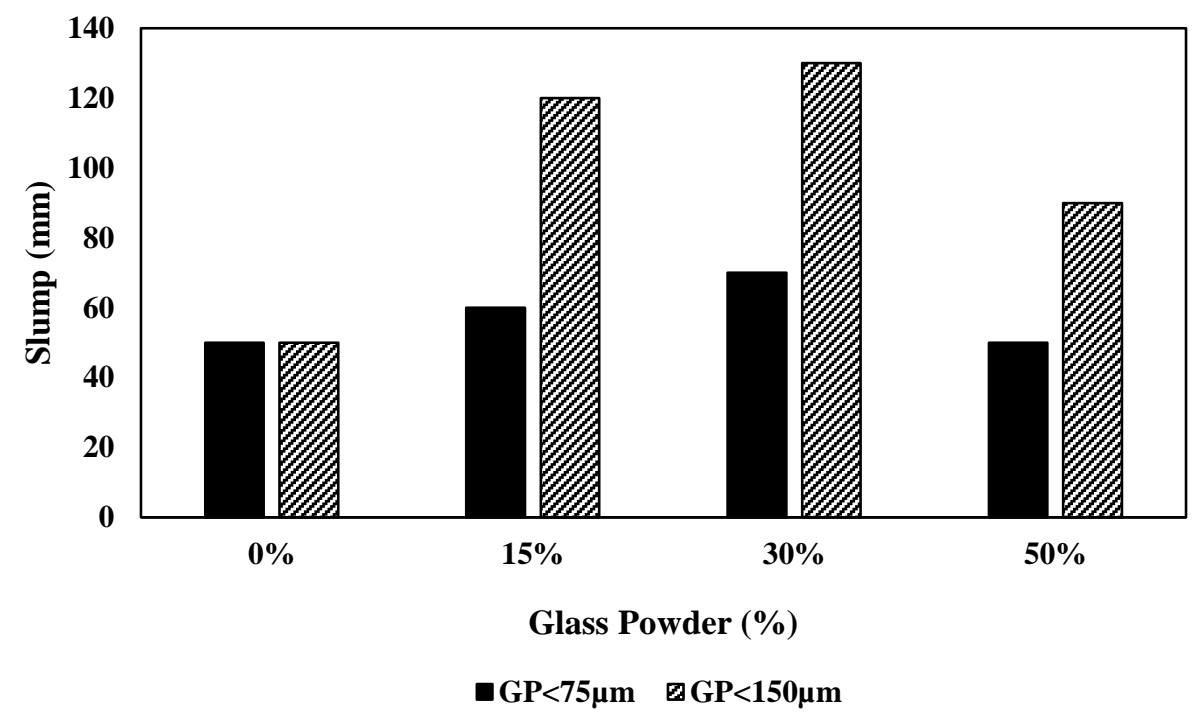

Figure 4. Workability of the mixes. 


\subsubsection{Compressive strength - Stage 1}

The compressive strength results for both the GPs at different curing ages are illustrated in Figure 5. Both the GPs exhibited a similar trend of decrease in strength with the increase of the GP replacement level at all curing ages. There is a linear pattern in the strength reduction with $50 \%$ replacement giving the least strengths in both the GPs applied. The strength results of the control mix are same in both the GPs as it was done only once in order to avoid wastage of time and materials owing to repetition but is shown twice in the results for better comparison. All the mixes irrespective of the GP used and regardless of the replacement level showed an increase in strength with the curing age indicating progressive hydration reaction. The fine GP at $15 \%$ and $30 \%$ substitution reported maximum compressive strength of $39 \mathrm{MPa}$ and $31 \mathrm{MPa}$ respectively, while strengths of $38 \mathrm{MPa}$ and $28 \mathrm{MPa}$ were recorded by the coarse GP at same replacement level.

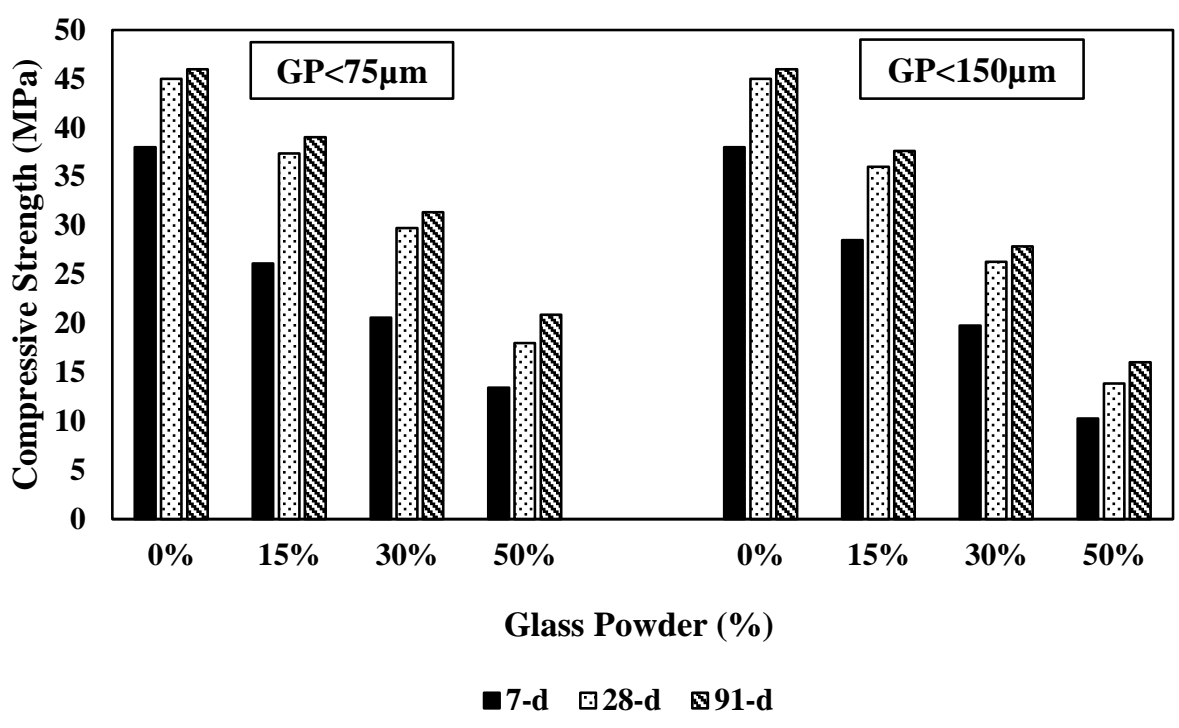

Figure 5. Compressive strength results - Stage 1.

\subsubsection{Strength Activity Index (SAI) - Stage 1}

The SAI values of the mixes is given in Figure 6. The pozzolanic performance of GP may be estimated with SAI, which is the ratio between the strength of mortar containing GP and the strength of equivalent control mortar at the same age. According to ASTM C618 [48], for a material to be qualified as a pozzolan, the SAI should be greater than 75\%. GP replacement of $15 \%, 30 \%$ and $50 \%$ yielded maximum SAI values of $85 \%, 68 \%$ and $45 \%$ with fine GP while highest SAI of $82 \%, 61 \%$ and $35 \%$ were reported by coarse GP at same replacement levels respectively. These results specify that the performance of the fine GP was slightly better compared to its coarse counterpart. Similar findings in which the fine GP performed better than its coarse equivalent are reported in literature in several occasions [23, 36, \& 46]. GP at 15\% is the ideal replacement level since it showed the maximum SAI values of all the substitution percentages employed. 


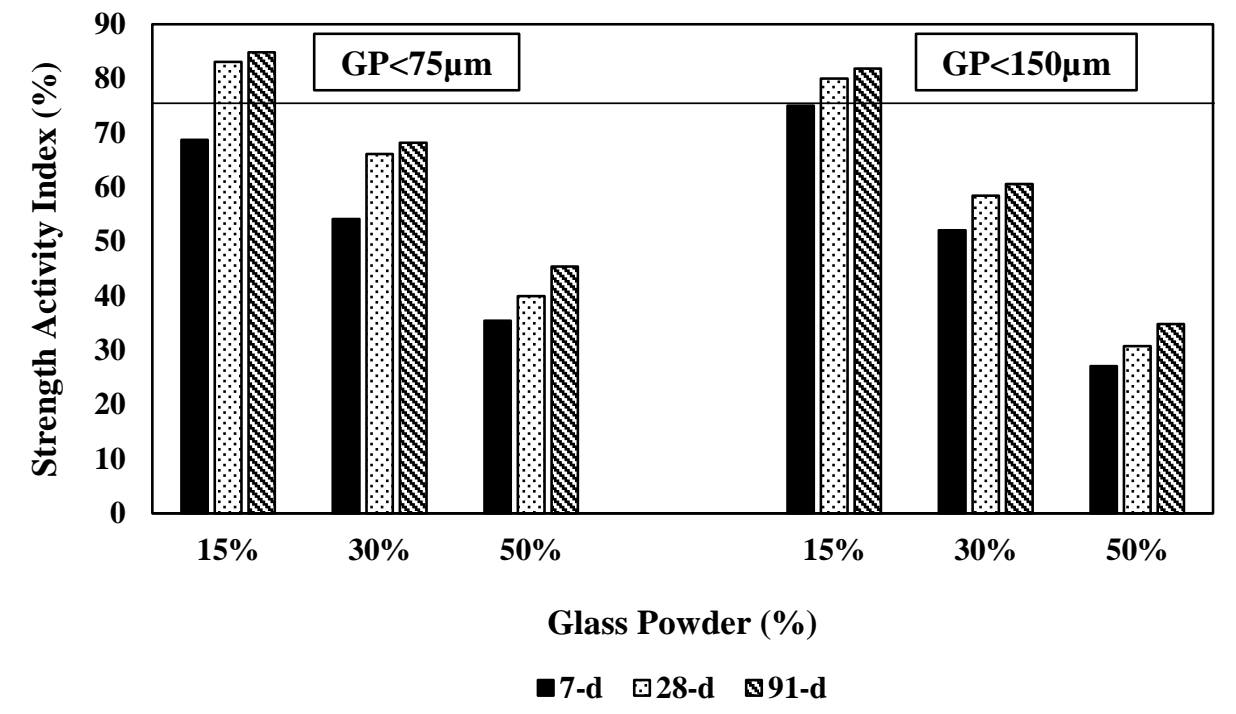

274

Figure 6. Strength activity index of Stage 1 GP mixes with different sizes.

As can be seen from Figure 6, the results for coarse GP were quite comparable with their fine counterparts, considering the fact that considerable amount of energy would be utilised in grinding the particles finer which would eventually increase the construction cost. Hence, to save the energy consumption and cost, the coarse GP was employed in stage two with varying curing conditions to optimise the replacement level and enhance the pozzolanic performance of the GP. In summary, Stage 2 results exhibited that the ideal replacement level increased from $15 \%$ to $30 \%$ and the SAI values were significantly improved from $61 \%$ to $89 \%$. These results are discussed in some detail in the subsequent sections.

\subsection{Stage 2 results}

\subsubsection{Workability - Stage 2}

The workability of the mixes is shown in Table 6. The trend exhibited was similar to previous stage results, as the GP content increases the workability rises, however, the magnitude of slump was lower compared to prior due to lower water to binder ratio employed. It can be seen that mix with $30 \%$ GP recorded a maximum slump of $90 \mathrm{~mm}$ which is approximately double that of the control mix with $0 \%$ GP. Mix with 50\% GP gave the least slump of $40 \mathrm{~mm}$ which is slightly below that of the control mix. GP substitution tends to increase the slump: this increase in workability is most likely due to the lower water absorption of the GP compared to the cement and increase in effective water to cement ratio in GP modified mixes. Another possible reason for this positive outcome may be due to the reduced specific surface area, since the GP used in the current study is coarser than the cement and hence a lower amount of water was consumed, which resulted in an increase in slump for the GP mixes. Zhen Chen and Chi Sun Poon [55] reported similar slump increase by employing milled GP at $10 \%$ and $20 \%$ replacement level, the median size of the used milled GP was 11.38 $\mu \mathrm{m}$ and a flow table technique was used to evaluate the workability of the mixes. It is a wellknown fact that workability doesn't influence strength directly but this increased workability can be used to produce GP mixes with lower water to cement ratio for a given cement content, 
thereby producing concrete with similar workability, improved strength and better durability than the control mix [42].

Table 5 Workability of the mixes.

\begin{tabular}{cc}
\hline Glass Powder (\%) & Slump (mm) \\
\hline $0 \%$ & 50 \\
$15 \%$ & 70 \\
$30 \%$ & 90 \\
$50 \%$ & 40 \\
\hline
\end{tabular}

\subsubsection{Hardened density - Stage 2}

Hardened densities of all the mixes subjected to various curing conditions are depicted in Figure 7. It is clearly evident that irrespective of the curing condition employed, the density values decreased with the addition of GP. It is interesting to note that, for ambient and Elevated Temperature (ET) cured samples the highest densities were recorded in either 7 or 28 days but for water cured cylinders, all mixes reached their maximum density at 91 days. This improvement in the densities in water cured specimens particularly at longer curing duration of 91 days may be due to the persistent hydration reaction. Mixes with 50\% GP recorded the least densities of all the mixes regardless of the curing condition they were exposed to. In summary, compared to the control mix with $0 \%$ GP, 28-day densities of 50\% GP mix reduced by $14 \%, 11 \%$ and $6 \%$ in ambient, ET and water curing conditions, respectively. The possible reason for this decrease is due to the lower specific gravity of GP (2.56) compared to that of cement (3.15) used in the study. Since, GP is resulting in a less dense concrete, it would be apt in places where light weight concreting is preferred. Shayan and $\mathrm{Xu}$ [45] reported density reductions of 5\% and 3\% at 20\% and 30\% GP replacement levels respectively at 28 days of curing, while the size of the used GP was $10-15 \mu \mathrm{m}$.

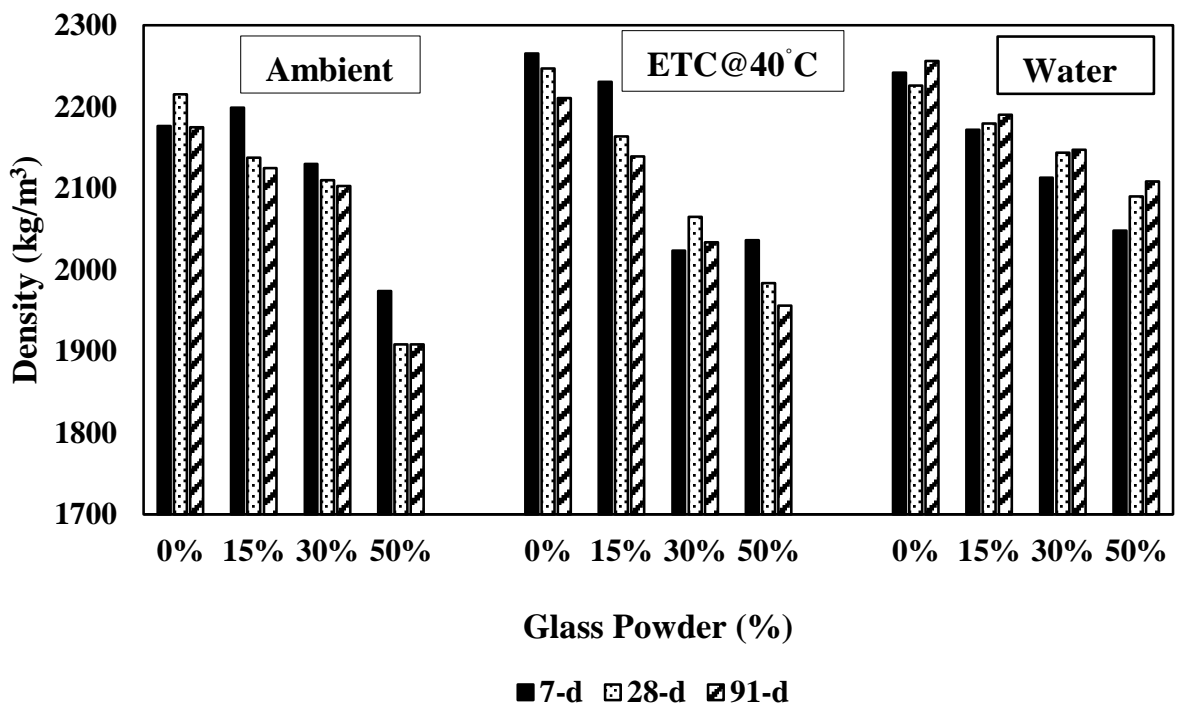

Figure 7. Hardened densities of mixes at 7 days, 28 days and 91 days of curing. 


\subsubsection{Compressive strength - Stage 2}

The results for the compressive strengths of the mixes exposed to different curing conditions and at distinct curing ages are shown in Figure 8. There is a decrease in the strength with the increase in GP replacement, while the reduction is more prominent in the early curing period of seven days, the lessening effect is weakened at prolonged curing of 91 days, particularly with 15\% and 30\% GP mixes. This improved performance of GP mixes particularly at longer curing periods is due to the formation of secondary C-S-H gel formed due to reaction between amorphous silica present in GP and $\mathrm{Ca}^{2+}$ from lime in presence of water. At 91 days of ETC, the lowest reduction in strength of $4 \%$ was recorded by mix with $15 \%$ GP and at the same age ambient cured mix with $30 \%$ GP showed a strength reduction of only $13 \%$. Mix with $50 \%$ GP did not show acceptable results as the earlier studies had shown that the pozzolanic reaction ceases beyond a replacement level of $30 \%$ due to absence of lime [35, 40]. In such cases, the additional GP would be acting as an inert filler. Considering the fact that the $0 \%$ GP or control mix was designed for $50 \mathrm{MPa}, 15 \%$ and $30 \%$ GP substitution yielded 28-day compressive strengths of 45 and $39 \mathrm{MPa}$, respectively. Also, due to the secondary hydration caused by pozzolanic effect, the strengths increased to 49 and $45 \mathrm{MPa}$, respectively, at 91 days of curing. These results validate the pozzolanic attribute of the GP used in the current research.

As for the effect of different types of curing on the pozzolanic performance of the GP, as expected 7 day ET cured samples showed highest strength irrespective of the mix indicating the increment in rate of hydration due to enhanced temperature. However, at extended curing duration of 91 days, both ambient and water cured samples showed slightly better strength compared to the ET cured specimens at replacement percentage of $30 \%$.

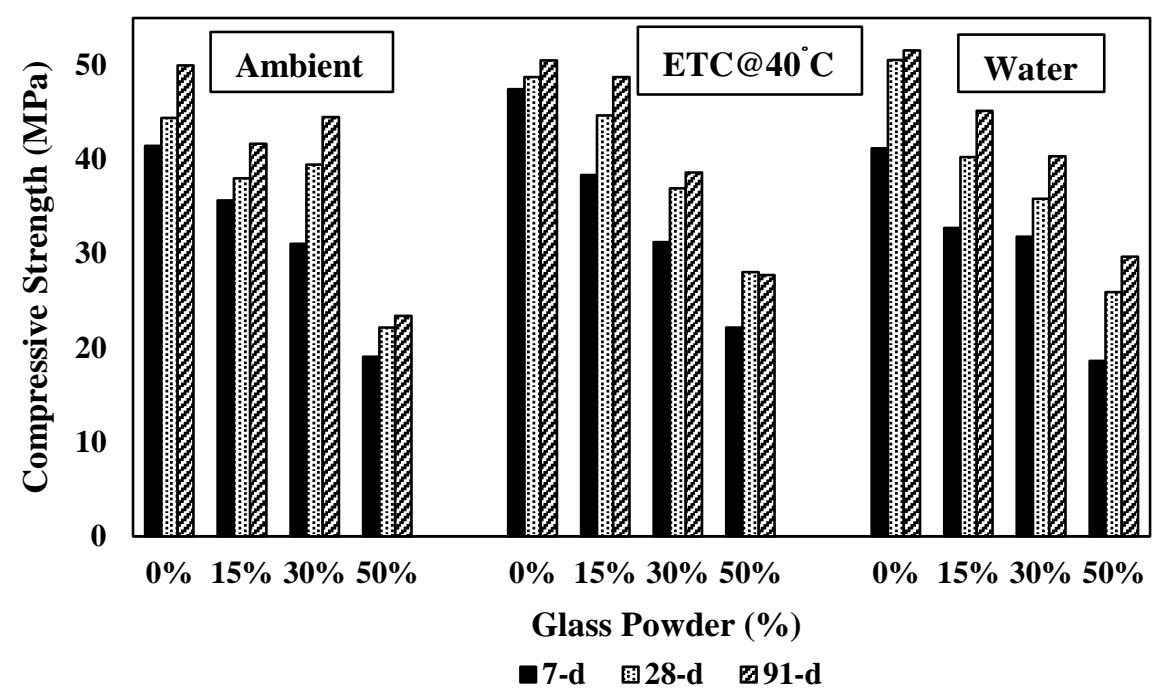

\subsubsection{SAI - Stage 2}

The SAI values of all the mixes containing GP are depicted in Figure 9. The mixes with $15 \%$ and $30 \%$ GP had SAI values of greater than $75 \%$ for all curing conditions, validating the pozzolanic characteristic of the GP used in the current research. The highest SAI values of 81\%, 92\% and 96\% were recorded for mixes with 15\% GP at 7, 28 and 91 days, respectively, all being subjected to ETC, while 30\% GP ambient cured samples have shown maximum SAI 
values of $75 \%, 89 \%$ and $89 \%$ at similar age. Although, mixes with $15 \%$ GP showed higher SAI values, 30\% GP is treated as the ideal replacement level since it is the highest possible GP substitution which exhibited almost similar SAI values compared to the mixes with 15\% GP. Similar research findings were reported by another study employing fine GP (mean size $8 \mu \mathrm{m}$ ) at $30 \%$ replacement, the SAI recorded were $80 \%$ and $90 \%$ at 28 and 91 days of curing respectively [56]. Furthermore, Rahma et. al [57] reported slightly better SAI values of over $90 \%$ with a coarse GP (mean size $200 \mu \mathrm{m}$ ) at 15\% replacement level.

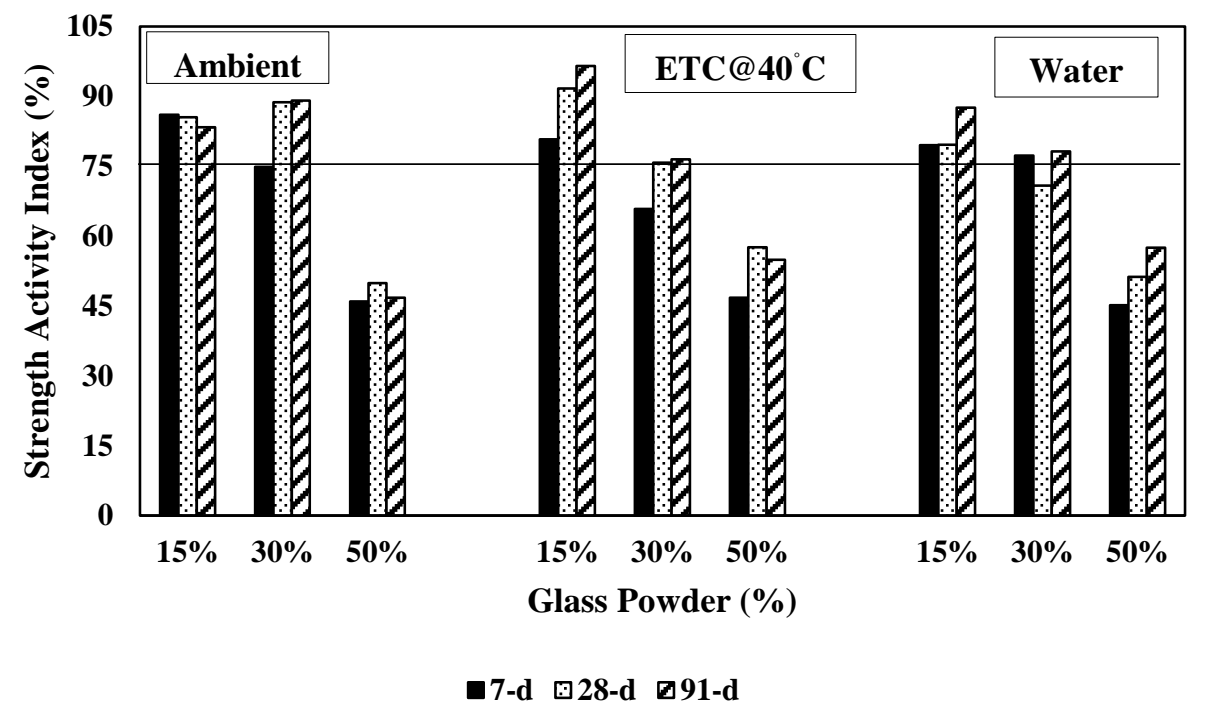

Figure 9. Strength activity index of GP mixes.

\subsubsection{Resistance to chloride ion penetration - Stage 2}

Resistance to chloride ion penetration was measured by using Resipod as shown in Figure 10. Since ambient and ET cured samples exhibited the best pozzolanic performance as discussed in the previous section, cylinders subjected to ambient and ETC were evaluated for measuring the resistance using Resipod. The feasibility of chloride ion penetration depending on the resistance values is given in Table 4, based on the calculated resistivity the mixes fall in several categories of risk.

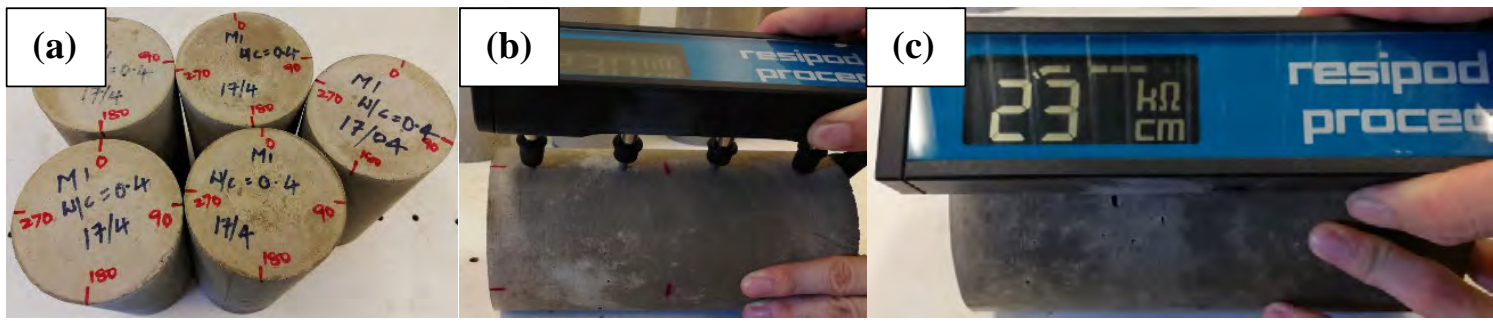

Figure 10. Resistivity measurements: (a) cylinder marking; (b) alignment; and (c) recording.

As shown in Figure 11, as the GP content increases, the resistivity values increase resulting in decrease in chloride ion penetration. At 28 days, ambient cured cylinders with $0 \%, 15 \%$, $30 \%$ and $50 \%$ GP exhibited resistances of $13,12,12$ and $18 \mathrm{k} \Omega \mathrm{cm}$, respectively, while the 
corresponding ET cured specimens showed values of $14,13,15$ and $16 \mathrm{k} \Omega \mathrm{cm}$, respectively. Resistances of 18,17, 20 and $82 \mathrm{k} \Omega \mathrm{cm}$ were recorded for ambient cured specimens with $0 \%$, 15\%, 30\% and 50\% GP, respectively, all at 91 days. The corresponding ET cured samples displayed resistances of $17,18,22$ and $78 \mathrm{k} \Omega \mathrm{cm}$.

ETC improved the resistances in all mixes and for both curing periods excepting with the mix with 50\% GP, in which ambient cured specimens showed slightly better resistances for both curing ages. Mixes with 50\% GP showed the highest resistances for both curing conditions and periods. A 50\% substitution of GP increased the resistance from 13 to $18 \mathrm{k} \Omega \mathrm{cm}$ for 28-day ambient cured specimens likewise, for ET cured cylinders, the resistance changed from 14 to $16 \mathrm{k} \Omega \mathrm{cm}$ for the same duration. However, for 91 days of curing, mixes with $50 \%$ GP exhibited more stupendous rise in resistance being from 18 to $82 \mathrm{k} \Omega \mathrm{cm}$ and 17 to $78 \mathrm{k} \Omega \mathrm{cm}$ for ambient and ET cured cylinders, respectively.

This increments in resistances in GP replacement of 50\%, particularly for longer curing ages, may be due to the combined effect of pozzolanic reaction, increased hydration and reduction in voids which resulted in microstructural refinements in GP mixes. Another study in which similar huge rise in chloride resistance by GP replacement was reported by Du and Tan [33], the technique adopted was Rapid Chloride Permeability Test (RCPT) and the size of the GP and maximum replacement level employed were $0-100 \mu \mathrm{m}$ and $60 \%$ respectively. Similar technique was employed on concrete made with 30\% GP at a curing age of 90 days resulting in very low chloride ion penetrability compared to the reference mix, however, the median size of the used GP was $8 \mu \mathrm{m}$, much finer than the one employed in the present study [56].

\section{Research significance}

As mentioned before, waste GP use as cement replacement can have a dual beneficial effect on the environment. Firstly, decrease in $\mathrm{CO}_{2}$ emissions since GP use as cement replacement would lead to decrease in cement consumption thereby resulting in lowering cement production. Secondly, reduction in dumping a non-biodegradable material in landfill, resulting in saving the limited landfill spaces and lessening the unsustainable effect of discarding waste GP in the open spaces. According to a recent report, Australian cement production is about 9.7 million tons in 2015-2016 which generated around 5.3 million tons of $\mathrm{CO}_{2}$ emissions in the atmosphere [58]. The investigative experimental study presented herein confirmed $30 \%$ as the ideal replacement level which if employed as cement replacement would lead to decrease in $\mathrm{CO}_{2}$ emissions by 1.6 million tons per annum in Australia and globally the annual $\mathrm{CO}_{2}$ discharge can be reduced by approximately 750 million tons. In addition to the positive environmental effects, employing waste GP in place of cement would lead to economical construction. Recycling a ton of GP consumes about $6.5 \mathrm{KW}$ of electric power, $1 \mathrm{~L}$ of diesel and $0.27 \mathrm{~L}$ of gasoline. These data have been obtained from the company which supplied the GP for the current study. So, by summing up the costs of the fuels employed, recycling 1 ton of GP costed about AUD 200, while the present price of general purpose cement in local market is approximately AUD 300-330/ton. A 30\% replacement of GP would result in savings of about AUD 800 million/annum in Australia, while globally the reduction in cost would be much higher. 


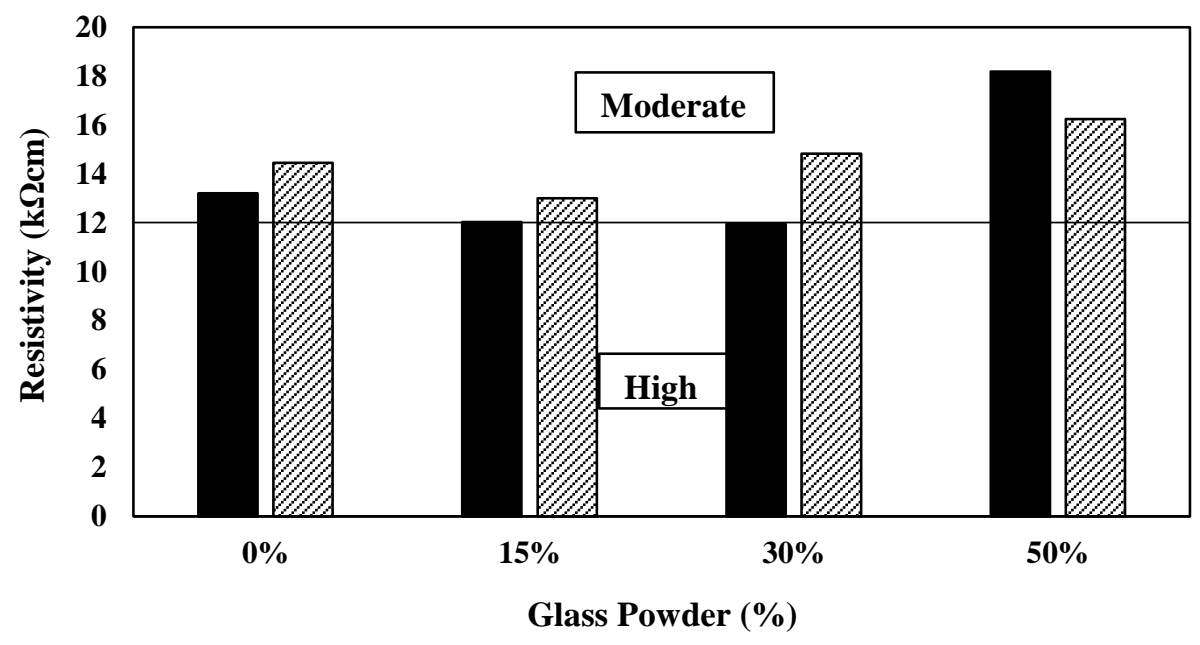

- 28-d Ambient 0 28-d ETC@40 ${ }^{\circ} \mathrm{C}$

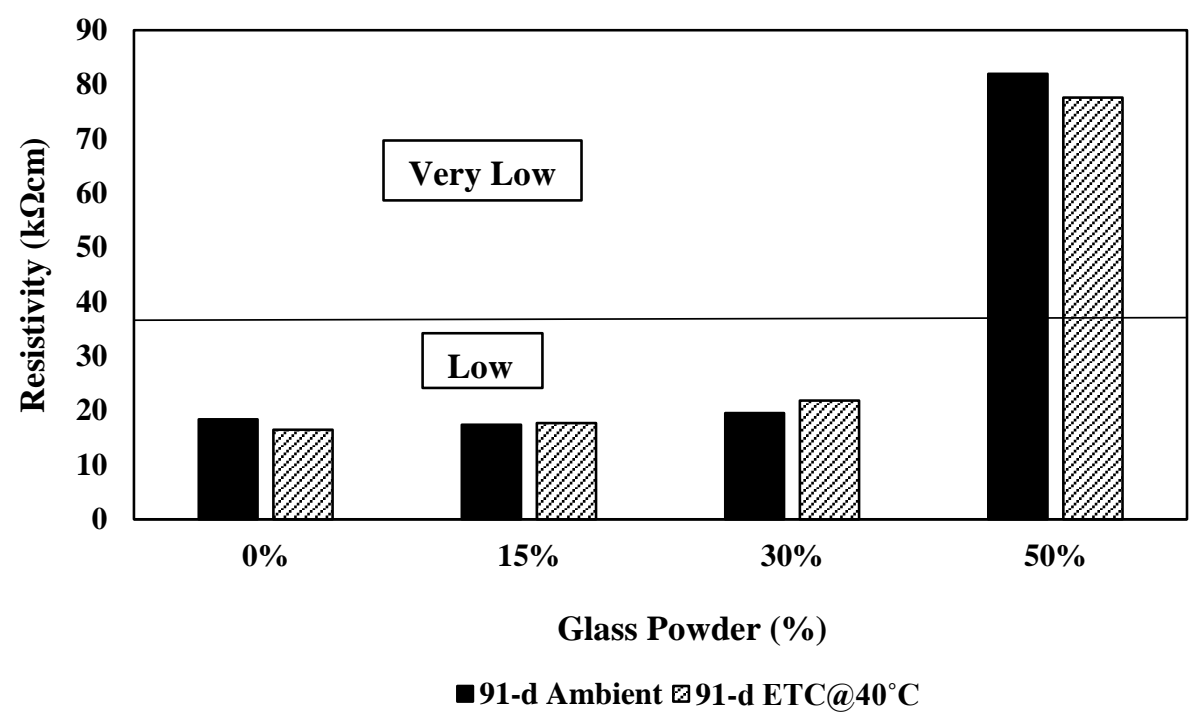

Figure 11. Chloride resistance of GP mixes: (a) 28-days; and (b) 91-day

\section{Conclusions}

Unlike previous researches on use of GP as replacement of cement for concrete, the current investigative study employed a coarse GP as cement replacement. A thorough investigation into the overall performance of coarse GP has been carried out and the initial experimental results are very encouraging. The following conclusions can be drawn from these findings:

1. There is an increase in workability with the GP substitution, particularly mixes with $30 \%$ GP recorded the highest slump the value of which is almost double that for the control mix ( $0 \% \mathrm{GP})$.

2. Hardened density results indicate that GP replacements lead to lighter concrete thereby facilitating its use in places where light weight concreting is required.

3. Compared to a control mix with design strength of $50 \mathrm{MPa}$, GP mixes with $15 \%$ and $30 \%$ cement replacement resulted in compressive strengths of $49 \mathrm{MPa}$ and $45 \mathrm{MPa}$, respectively at 91 days of curing. 
4. As expected, ETC resulted in increases in the compressive strengths, particularly at early curing age of 7 days. However, this positive effect was subsided at longer curing regimes of 91 days and at higher replacement levels of $50 \%$.

5. Mixes with $15 \%$ and $30 \%$ GP showed SAI values of greater than $75 \%$ irrespective of the curing condition and for all curing ages. This conforms to the requirements of ASTM C 618 and hence the confirmation of the use of GP as a pozzolanic material in concrete in the current investigative study.

6. GP utilised in the current research produced an incremental increase in the resistivity, especially mixes with 50\% GP recorded a fourfold rise in resistance to chloride ion penetration compared to the control mix with $0 \%$ GP, thereby significantly reducing the probability of steel corrosion due to chloride ions in reinforced concrete members.

7. In order to get the maximum benefit, a higher percentage of GP substitution is preferred. Hence, $30 \%$ is considered as the ideal replacement level for the GP employed in the current experimental study since it showed better results compared to the other replacement levels for fresh, mechanical and durability properties of concrete made using these mixes.

8. Use of recycled waste GP as cement replacement in construction industry would have a dual beneficial effect environmentally and a significant valuable effect economically as discussed herein.

\section{Acknowledgements}

The authors would like to acknowledge School of Engineering and Built Environment, Griffith University, for providing laboratory and financial support for the research project. A special thanks to Mr. Paul Howard and Mr. Des Chalmers (Envirosand, Brisbane) for providing the glass powder for the experimental study.

\section{References}

[1] Edwards, P. (2017). Global Cement Top 100 Report 2017-2018. Global Cement Magazine, 17.

[2] Stafford, F. N., Dias, A. C., Arroja, L., Labrincha, J. A., \& Hotza, D. (2016). Life cycle assessment of the production of Portland cement: a Southern Europe case study. Journal of cleaner production, 126, 159-165.

[3] Szabó, L., Hidalgo, I., Ciscar, J. C., \& Soria, A. (2006). CO2 emission trading within the European Union and Annex B countries: the cement industry case. Energy policy, 34, 72-87.

[4] Oreskes, N., \& Conway, E. M. (2011). Merchants of doubt: How a handful of scientists obscured the truth on issues from tobacco smoke to global warming. Bloomsbury Publishing USA.

[5] Gopalakrishnan, R., \& Govindarajan, D. (2011). Compressive strength and electron paramagnetic resonance studies on waste glass admixtured cement. New Journal of Glass and Ceramics, 1, 119. 

Modulus of rupture evaluation of cement stabilized recycled glass/recycled concrete aggregate blends. Construction and Building Materials, 84, 146-155.

490

491

492

493

494

495

496

497

498

499

500

501

502

503

504

505

506

507

508

509

510

511

512

513

514

515

516

517

518

519

520

521

522

523

524

[7] Liu, F., Meng, L. Y., Ning, G. F., \& Li, L. J. (2015). Fatigue performance of rubbermodified recycled aggregate concrete (RRAC) for pavement. Construction and Building Materials, 95, 207-217.

[8] Lotfi, S., Eggimann, M., Wagner, E., Mróz, R., \& Deja, J. (2015). Performance of recycled aggregate concrete based on a new concrete recycling technology. Construction and building materials, 95, 243-256.

[9] Shang, H. S., Zhao, T. J., \& Cao, W. Q. (2015). Bond behavior between steel bar and recycled aggregate concrete after freeze-thaw cycles. Cold Regions Science and Technology, 118, 38-44.

[10] Silva, R. V., Neves, R., De Brito, J., \& Dhir, R. K. (2015). Carbonation behaviour of recycled aggregate concrete. Cement and Concrete Composites, 62, 22-32.

[11] Pepe, M., Toledo Filho, R. D., Koenders, E. A., \& Martinelli, E. (2016). A novel mix design methodology for Recycled Aggregate Concrete. Construction and Building Materials, 122, 362-372.

[12] Wang, Z., Shi, C., \& Song, J. (2009). Effect of glass powder on chloride ion transport and alkali-aggregate reaction expansion of lightweight aggregate concrete. Journal of Wuhan University of Technology-Mater. Sci. Ed., 24, 312-317.

[13] Jain, J. A., \& Neithalath, N. (2010). Chloride transport in fly ash and glass powder modified concretes-influence of test methods on microstructure. Cement and Concrete Composites, 32, 148-156.

[14] Nassar, R. U. D., \& Soroushian, P. (2012). Green and durable mortar produced with milled waste glass. Magazine of Concrete Research, 64, 605-615.

[15] Shayan, A. (2002). Value-added utilisation of waste glass in concrete. In IABSE Symposium Report, International Association for Bridge and Structural Engineering, 86, 1221.

[16] Pickin, J., \& Randell, P. (2017). Australian national waste report 2016. Department of the Environment and Energy.

[17] Pereira-de-Oliveira, L. A., Castro-Gomes, J. P., \& Santos, P. M. (2012). The potential pozzolanic activity of glass and red-clay ceramic waste as cement mortars components. Construction and Building Materials, 31, 197-203.

[18] Zhang, T., Gao, P., Gao, P., Wei, J., \& Yu, Q. (2013). Effectiveness of novel and traditional methods to incorporate industrial wastes in cementitious materials-An overview. Resources, Conservation and Recycling, 74, 134-143.

[19] Johnston, C. D. (1974). Waste glass as coarse aggregate for concrete. Journal of Testing and Evaluation, 2, 344-350. 
[20] Topcu, I. B., \& Canbaz, M. (2004). Properties of concrete containing waste glass. Cement and concrete research, 34, 267-274.

[21] Saccani, A., \& Bignozzi, M. C. (2010). ASR expansion behavior of recycled glass fine aggregates in concrete. Cement and Concrete Research, 40, 531-536.

[22] Taha, B., \& Nounu, G. (2008). Using lithium nitrate and pozzolanic glass powder in concrete as ASR suppressors. Cement and Concrete Composites, 30, 497-505.

[23] Shao, Y., Lefort, T., Moras, S., \& Rodriguez, D. (2000). Studies on concrete containing ground waste glass. Cement and Concrete Research, 30, 91-100.

[24] Duchesne, J., \& Bérubé, M. A. (1994). The effectiveness of supplementary cementing materials in suppressing expansion due to ASR: another look at the reaction mechanisms part 2: pore solution chemistry. Cement and Concrete Research, 24, 221-230.

[25] Ramlochan, T., Thomas, M., \& Gruber, K. A. (2000). The effect of metakaolin on alkalisilica reaction in concrete. Cement and concrete research, 30, 339-344.

[26] Rajabipour, F., Maraghechi, H., \& Fischer, G. (2010). Investigating the alkali-silica reaction of recycled glass aggregates in concrete materials. Journal of Materials in Civil Engineering, 22, 1201-1208.

[27] Tan, K. H., \& Du, H. (2013). Use of waste glass as sand in mortar: Part I-Fresh, mechanical and durability properties. Cement and Concrete Composites, 35, 109-117.

[28] Du, H., \& Tan, K. H. (2014). Effect of particle size on alkali-silica reaction in recycled glass mortars. Construction and Building Materials, 66, 275-285.

[29] Mehta, P. K. (2002). Greening of the concrete industry for sustainable development. Concrete international, 24, 23-28.

[30] Du, H., \& Tan, K. H. (2015). Transport properties of concrete with glass powder as supplementary cementitious material. ACI Materials Journal, 112, 429.

[31] Kamali, M., \& Ghahremaninezhad, A. (2016). An investigation into the hydration and microstructure of cement pastes modified with glass powders. Construction and Building Materials, 112, 915-924.

[32] Omran, A., \& Tagnit-Hamou, A. (2016). Performance of glass-powder concrete in field applications. Construction and Building Materials, 109, 84-95.

[33] Du, H., \& Tan, K. H. (2017). Properties of high volume glass powder concrete. Cement and Concrete Composites, 75, 22-29.

[34] He, Z. H., Zhan, P. M., Du, S. G., Liu, B. J., \& Yuan, W. B. (2019). Creep behavior of concrete containing glass powder. Composites Part B: Engineering, 166, 13-20.

[35] Elaqra, H. A., Haloub, M. A. A., \& Rustom, R. N. (2019). Effect of new mixing method of glass powder as cement replacement on mechanical behavior of concrete. Construction and Building Materials, 203, 75-82. 
[36] Patel, D., Tiwari, R. P., Shrivastava, R., \& Yadav, R. K. (2019). Effective utilization of waste glass powder as the substitution of cement in making paste and mortar. Construction and Building Materials, 199, 406-415.

[37] Lee, H., Hanif, A., Usman, M., Sim, J., \& Oh, H. (2018). Performance evaluation of concrete incorporating glass powder and glass sludge wastes as supplementary cementing material. Journal of Cleaner Production, 170, 683-693.

[38] Zheng, K. (2016). Pozzolanic reaction of glass powder and its role in controlling alkalisilica reaction. Cement and Concrete Composites, 67, 30-38.

[39] Aliabdo, A. A., Elmoaty, A. E. M. A., \& Aboshama, A. Y. (2016). Utilization of waste glass powder in the production of cement and concrete. Construction and Building Materials, 124, 866-877.

[40] Siad, H., Lachemi, M., Sahmaran, M., \& Hossain, K. M. A. (2016). Effect of glass powder on sulfuric acid resistance of cementitious materials. Construction and Building Materials, 113, 163-173.

[41] Kamali, M., \& Ghahremaninezhad, A. (2015). Effect of glass powders on the mechanical and durability properties of cementitious materials. Construction and Building Materials, 98, 407-416.

[42] Sharifi, Y., Afshoon, I., \& Firoozjaie, Z. (2015). Fresh properties of self-compacting concrete containing ground waste glass microparticles as cementing material. Journal of Advanced Concrete Technology, 13, 50-66.

[43] Mirzahosseini, M., \& Riding, K. A. (2014). Effect of curing temperature and glass type on the pozzolanic reactivity of glass powder. Cement and Concrete Research, 58, 103-111.

[44] Matos, A. M., \& Sousa-Coutinho, J. (2012). Durability of mortar using waste glass powder as cement replacement. Construction and building materials, 36, 205-215.

[45] Shayan, A., \& Xu, A. (2006). Performance of glass powder as a pozzolanic material in concrete: A field trial on concrete slabs. Cement and concrete research, 36, 457-468.

[46] Shi, C., Wu, Y., Riefler, C., \& Wang, H. (2005). Characteristics and pozzolanic reactivity of glass powders. Cement and Concrete Research, 35, 987-993.

[47] Standards Australia. (2010). AS 3972. General purpose and blended cements. Standards Australia, Sydney, NSW, Australia

[48] Astm, C. (2003). 618. Standard specification for fly ash and raw or calcined natural pozzolan for use as a mineral Admixture in Portland Cement Concrete.

[49] Standards Australia. (2014). 1012.8. 1: Methods of testing concrete-Method for making and curing concrete-Compression and indirect tensile test specimens. Standards Australia, Sydney, NSW, Australia.

[50] Standards Australia. (1998). AS 1012.3. 1-1998. Methods of testing concreteDetermination of properties related to the consistency of concrete. Standards Australia, Sydney, NSW, Australia. 
605

606

607

608

609

610

611

612

613

[51] Standards Australia. (1998). AS 1012.12.1-1998, Method 12.1: Determination of mass per unit volume of hardened concrete - Rapid measuring method. Standards Australia, Sydney, NSW, Australia.

[52] Standards Australia. (2014). AS 1012.9 Methods of testing concrete-Compressive strength tests-Concrete, mortar and grout specimens. Standards Australia, Sydney, NSW, Australia.

[53] TP95, A. A. S. H. T. O. (2011). 11: Standard Method of Test for Surface Resistivity Indication of Concrete's Ability to Resist Chloride Ion Penetration. American Association of State Highway and Transportation Officials, Washington, DC.

[54] Hamilton, H. R., Boyd, A. J., \& Vivas, E. A. (2007). Permeability of concrete-comparison of conductive and diffusion methods. Final Report submitted to Florida Department of Transportation" (Contract No. BD536).

[55] Chen, Z., \& Poon, C. S. (2017). Comparing the use of sewage sludge ash and glass powder in cement mortars. Environmental technology, 38(11), 1390-1398.

[56] Chaïd, R., Kenaï, S., Zeroub, H., \& Jauberthie, R. (2015). Microstructure and permeability of concrete with glass powder addition conserved in the sulphatic environment. European Journal of Environmental and Civil Engineering, 19(2), 219-237.

[57] Rahma, A., El Naber, N., \& Issa Ismail, S. (2017). Effect of glass powder on the compression strength and the workability of concrete. Cogent Engineering, 4(1), 1373415.

[58] CIF. (2017). Cement Industry Federation Industry Report 2017. Cement Industry Federation, Forrest, ACT, Australia. 